\title{
Virtual Piety and Muslim Traditionalism Mainstreaming: The Digital Activism of Bangkitmedia.com and Kyaiku.com
}

\author{
Luthfi Rahman \\ Universitas Islam Negeri WaliSongo Semarang, Indonesia \\ email luthfirahman@walisongo.ac.id
}

\begin{abstract}
Abstrak
Penelitian ini memfokuskan pada kajian dua situs berita bangkitmedia.com dan kyaiku.com yang cukup gencar melakukan digital activism dengan mengupdate info berita mengenai nasihat dan perilaku kyai. Fenomena digital activism mengantarkan pada pertanyaan apa makna dibalik fenomena tersebut yang dilakukan oleh kaum santri dalam mewarnai diskursus di media sosial yang marak dewasa ini. Bagi penulis, dua situs portal berita tersebut mencoba untuk membangun virtual piety melalui narasi teks maupun video yang berupa ceramah, religiusitas dan kebijaksanaan hidup dari figur kyai. Fenomena virtual tersebut mengarahkan penulis untuk mempertanyakan apa yang melatarbelakangi digital activism dua situs tersebut. Artiekl ini menggunakan penelitian kualitatif yang metode pengumpulan datanya melalui wawancara serta dokumentasi dengan menggunakan pendekatan digital hermeneutik. Berdasarkan peneltian, adanya gerakan virtual kaum tradisionalis yaitu santri virtual. Maka penulis memiliki argumentasi bahwa virtual piety mengarahkan pada traditionalism mainstreaming yang berfungsi sebagai: media moderasi virtual dan kontra narasi radikal melalui konten narasi teks maupun video kyai.
\end{abstract}

Kata kunci: Bangkitmedia.com, kesalehan virtual, kyaiku.com, moderasi virtual

\begin{abstract}
This research focuses on two sites bangkitmedia.com and kyaiku.com which, in the last few years, have been quite intensive in doing digital activism through media sharing about advices and exemplary behaviours of traditional religious clerics or kyai. The phenomenon leads to questioning what behind the digital activism of the two sites is. This paper aims to know and comprehend how such activism within bangkitmedia.com and kyaiku.com has been going through in coloring social media and what message they try to convey to netizens. This is a qualitative research that collects the data from interview and documentation
\end{abstract}


from both websites and analysis them by a digital hermeneutic approach. It found that through the webs, they have built a virtual piety through posted texts or videos that contain religious sermons and testimonies from other people on the religiosity and wisdom of the kyai during and after their lives. Besides, this virtual piety refers to traditionalism mainstreaming which functions as: virtual moderation media and also countering radical narrative.

Keywords: Bangkitmedia.com, kyaiku.com, virtual moderation, virtual piety

\section{Introduction}

What so-called as media convergence becomes a pivotal sign for the rise of new media. The convergence designates "a three-in-one media" involving three main elements i.e., "telecommunications, data communication and mass communication in one medium" (Nasrullah, 2014). In such media, some authorities belong to users in terms of "developing and utilizing texts." Also, freedom to transform the texts is possessed by users to get benefit from other users in order to make communication among and between them "more interactive." In this case, such communication is more likely delivered via texts and possible symbols understood by the users.

Accordingly, it should be understood further that the era of information revolution undergoing in society today brings most individuals to be part of two communities, i.e., a visual/real society, and of a virtual community. The spread of social media in the past few years has made it almost impossible for every member of the community to escape from the frenzy of social media such as Facebook, WA, Instagram, Twitter and others (Gunawan, 2012). Those media are the most widely used in community for communicative activities, there are even some people whose interactions on social media exceed their face-to-face interactions. However, the development of social media has a positive influence, to ease communicative activities for the community. We can now call the global community as a global village since distance and time are not obstacles anymore. The technology can shorten views, hearing and touch, beyond space and time (Mc Luhan 1968).

Related to media technology and religion, nowadays, there is a tight competition in the media industry, euphoria democracy, and fragile regulation. Weak functioning social control makes the country's media industry no longer provides the information needed by the public. Media has been working as the most dominant social device which produces various kinds of definition of social problems according to its own version, including in defining religiosity and audience spirituality (Hoover, 1997). It understandably indicates that the 
media power is, to some extent, able to impose religious textual (interpretation) to and be agreed upon by the audience.

In line with the situation, religion - to address its religious adherent takes part in bringing religious discourses into the media. In the Indonesian context, it can be seen from the mushrooming religious sites or apps in the internet. To look at such phenomena has to comprehend all aspects surrounding it. It is therefore the need for hermeneutical concern on the amalgamation between virtual religious narratives and social media, digital hermeneutics, is extremely necessary. This is due to the fact that social media is now the most widely read virtual commentary in Indonesia today. Indonesia is one of the countries with the most Facebook users. The results of a survey and research from the Ministry of Communication and Information in 2019 stated statistically that internet users in Indonesia are 150 million. $95 \%$ of them use social media and spend 3,5 hours per day for accessing it (Informatika, 2019).

As far as the issue of virtual activities is concerned, many today are making the web as a medium to spread certain ideas or thoughts that tend to show ideological, political and social affiliation. Speaking of hermeneutics, virtual religious narratives are quite widespread and certainly have broad meaning, including all forms of hermeneutical acceptance in the form of religious wisdom narratives in lecture texts, memes and videos. The rise of the web complete with the contents of the narration also indicates the growing enthusiasm of the virtual awareness growth. Among the hundreds or thousands of websites are bangkitmedia.com and kyaiku.com.

Such phenomena leads us to see that social media, used by elite and lay people, also becomes close to and rampant for traditional santri to participate in enlivening the virtual world and its dynamics through their creative webs by posting religious views, stories, and advices of kyai. The webs discussed in this study are bangkitmedia.com and kyaiku.com. Through these virtual webs, I argue that they present virtual piety as well as efforts to mainstream traditionalism to some extent, and to counter religious extremism softly. It is therefore noteworthy to address how these websites through their socioreligious narratives play role in coloring social media and what messages they try to convey? 


\section{Method}

The method used is a qualitative method through content analysis techniques (religious content) from religious narratives presented by bangkitmedia.com and kyaiku.om related to religious views that is often expressed by kyai. The content of this analysis is then combined with a digital hermeneutic approach. Digital hermeneutics is a meeting between hermeneutics and web technology, including virtual narratives created on the web. Traditionally, hermeneutics has been a theory of interpretation in the humanities. With the emergence of various websites and applications, this theory is needed to explain the interpretation of information in a digital environment. Digital hermeneutics forms the right context for thinking about providing access to and interpretation of online collections of cultural heritage institutions. The main objective is to investigate the relationship between human interpretation processes and Web applications that support that interpretation process (Capurro, 2010).

Hermeneutic analysis in the virtual universe certainly involves a variety of relevant disciplines that allow interpretation to be broader and deeper. However various structural elements that are symbolic cannot be dismantled by just looking at the relations between these elements. Therefore, interpretation in the perspective of hermeneutics also includes all the sciences that are possible to help shape it: psychology, sociology, politics, anthropology, history, and others. This is what is meant by three distances over the world of texts (objects) and appropriation or self-understanding. In other words, if the text (object) is understood through the analysis of relations between its elements (structural), other fields that have not been touched can be understood through other relevant and possible fields of science and methods (Haryatmoko, 2002).

\section{Digital's Hermeneutica}

To frame this study, I do consider that there are relevant theories in cementing the topic with its theoretical framework on social media. Kalamas in his particular topic on modeling social media use elucidates that social media is a communication medium devoted to or characterized by interaction between participants or consumers of the medium, i.e., as a means of communication in the interaction between participants or customers of a media designed to expand human social interaction using internet and web technology (Kalamas, Mitchell, \& Lester, 2009). Meanwhile, Social media as 
defined by is "a media designed to engage the public and create a social impact", since it has succeeded in transforming the practice of unidirectional broadcast media communication from one media institution to many audiences (one to many) into dialogical communication practices among many audiences (many to many) (Schuler, 2008).

Meanwhile, Horton explains that social media is, "every message is a work in progress that can be read or heard, updated at will, and often edited or commented upon by the recipient. And in many instances, the content may actually be created in part by the end user", i.e., social media supports knowledge and information in transforming from the user of the message contents into the maker of message contents (Horton, 2008).

Furthermore, Mayfield states that social media is a means for users to participate in, share with each other and create messages, including blogs, social networks, 20 wikis or online encyclopedias, virtual forums, including virtual worlds. He elaborates more that it is best understood as a group of new types of online media that share several characteristics, including: a) Social media encourages contributions and feedback from everyone involved, biasing the boundaries between media and its users, b) Social media is open to feedback and participation through means of voting, commenting and sharing information. Rarely are there obstacles to accessing and utilizing content such as protected passwords, c) Conversations allow for conversations between users in "two directions". When old (traditional) media is about "broadcasts" in which content is transmitted or distributed to the audience, social media is more seen as a two-way conversation, d) Social media allows people to form a community quickly and communicate effectively. Community is a collection of people who have the same interests as photography lovers, and others, and e) Connections lead the majority of social media to thrives because of the ability to serve the connection between users, through facilities linking (links) to the website, sources of information and other users (Mayfield, 2008).

Many positive impacts can be taken from the development of social media but not a few problems that arise due to social media. One negative impact of the existence of social media is the development of hate speech which can take the form of insults, defamation, unpleasant acts, provoking, inciting, spreading hoaxes, so on and so forth. All the above actions have a purpose or can have an impact on acts of discrimination, violence, social conflict and even loss of life. In fact, the communication behavior of users of social media can be said to tend to acts of aggression on social media. Negative behavior on social 
media is already quite disturbing, especially concerning religious content and diversity. Blaspheming with each other in the name of God, prophet and religion is widespread on social media.

As a cyber-media, internet has its three convergences: a) Cyber-space which is closely related to media in the form of digital computer networks where communication between entities (both human and non-human) takes place. In its development, the term cyberspace "then understood not only as a network in technical aspects, but more broadly talking about social interaction, b) Cyber-society denoting a term in the rapid development of communication technology in the field of information, where interaction occurs between individuals, i.e., between users of the public space and the interaction has created a community environment, c) Cyber-culture showing any culture that has or is emerging from the use of computer networks for communication, entertainment and business. One characteristic of cyber-culture is that culture is formed through social relations that are not geographical, meaning that individuals in cyber-culture interact not because of geographical conditions, but because of a cognitive relationship using computer media such as culture in general aiming at building identity and credibility in a society (Tomic, Alice Laura Lengel, Crispin Thurlow, 2004).

In Bungin's theory on "cyber community" as the latest theory in the development of communication science or the sociology of communication, it emphasizes that social groups in cyberspace constructs the message of its users. From this point of view, it can be justified that the presence of technology in society can form a culture called technology. Humans nowadays tend to deify and hand the technology over to control all aspects of their lives (Bungin, 2009). Thurlow et al. reflects that social media as a cultural transformation, especially in social interactions. How do we see in the present that identity, relationship and community can be formed through social media, how we live and work depends on technology so that it is difficult to distinguish between users of social media in the non-dependency and dependency categories. The social interaction approach distinguishes the media based on how close the media is to the face-to-face interaction model (Thurlow, Lengel, \& Tomic, 2004).

In terms of relationship between users and technology, Turkle remains firm to investigate the intimacy between users and new technology. For him, some people treat computers as if the object is a human being that we pay attention to and as a place for emotional overflow. That is, there is user comfort 
in online communication as self-disclosure and interaction with the media rather than directly with other humans (Turkle, 2005).

In addition, Jacobs stated that another approach is the integration of social media not in the form of information, interaction or dissemination but in the form of ritual. From the point of view of social interaction, social media creates a new understanding of interactive personal communication. Social media is not like direct interaction (face to face), but provides a new form of interaction that brings users back to interpersonal relationships, namely in the form of computer-based interaction. Through social media, individuals can interact with each other in real time (Jacobs, 2007). Therefore, the reality in society can also be seen from what kind of interactivity of the community in using internet, be they consumptive or a wise one. For doing the latest as quoted by Lestari from Bakardijeva, it requires the activeness of society in playing its function in the social process for creating reciprocal relationships related to knowledge and daily life (Lestari, 2018).

So, various advantages and disadvantages derived from mediated interactions, new media may provide flexible time in use, but also create new time demands. For example, social media users can interact through chat applications anytime and anywhere, but they will tend to spend a lot of time on the same thing every day. Then social media from the viewpoint of social integration is no different from television media. Media are both used as a form of ritual. That is, humans do not use media only to the notice of information, but because using media has become a habit. For example, after waking up someone immediately checks a smartphone and opens a social media application. It is frequent and daily and may be done not only to seek information, but also to become a habit. The pattern use of ritual in the perspective of research of activities and selectivity asserts that the use of media refers to the habits and frequency of use by people with strong relationships with the media

Through aforementioned theoretical encounters, we can realize that through two webs santri community can also be called as part of cyber community playing role in cyber discourse. Both webs inform and communicate messages about religious outlooks and views through their specific styles and methods, i.e., presenting the views and traditions of Muslim figures considered as authoritative. When referred to Bungin's theory, traditional Muslims represented by santri become, part and parcel, cyber community who tries to do campaign on virtual piety and Muslim traditional 
mainstreaming as the message for the users or netizens. From this context, social media seems to be eventually a media of "cultural transformation" for users since santri are intent to share religious views, admonitions and advices of Muslim traditional clerics in order to be regularly read by netizens. In this very point, the two webs can "create a new understanding of interactive personal communication." When the netizens frequently access them, they do not utilize them only for accessing information, but also for being "a habit."

\section{Kyai on the Media}

Digital hermeneutics is the reading and searching for meaning that lies behind virtual narratives that scatter on social media. In the virtual narrative discourse that is currently rife, this requires a deep conceptual awareness of the dynamics of religious narratives that are taking place on social media. Nowadays in Indonesia there has been a great cyber war involving radical religious groups that tend to pro-Khilafah campaigns as a model of the ideal State system. In another side, there are moderate religious groups that remain firm for the Republic of Indonesia by defending Pancasila and the 1945 Constitution. The radical religious groups always carry out posts that tend to be provocative, vilify others, disregard heresy and also reach the spread of hoaxes. Meanwhile, moderate religious groups in their dynamics in social media tend to reinforce the importance of unity, tolerance of the different, back to Pancasila and religiously polite.

The results of digital hermeneutic reading in the case of cyber war discourse between moderate and radical Islamic websites - especially in this very case - can be seen in the following description:

Level one: "Reality", Verbal and non-verbal words in the form of lectures both written and video and memes and etc. These are encoded virtually by technical codes such as; wise words of kyai, wird or litanies and sermon of kyai.

Level two: "Representation" Photos, memes and videos settings that transmit conventional representation codes, which form self-representation, for example; narrative, character, action, dialogue, setting, casting, etc.

Level three: "Ideology" Which is arranged into coherent and social acceptability through ideology, such as; traditionalism and modernism 
It is interesting to read the above figure through Syahputra's reading by borrowing Gurevitch's theory, reality in social media culture is a product of cultural codes because reality is always encoded, and never raw. One way to accept and to understand the reality encoded by social media is through the codes of the culture that surrounds it. If the encoded piece of reality enters social media, then it is transmitted technologically and eventually it will become a cultural text for the readers. In turn, some social codes that contain reality can be precisely defined through social media. Similar perceptions underlie the opinion that the media must be seen as "defining social reality". True, the phrase contains duality, the crucial ambiguity of the formulation, first there is reality, real reality and second, there is media and defining of the reality (Syahputra, 2016).

\section{The Digital Actvisime of Bangkit Media.com and Kiaiku.com}

This part discusses on how the two websites take part in coloring media discourse and reveals the message they try to deliver. The posts uploaded by bangkitmedia.com and kyaiku.com are sourced from traditional mainstream clerics such as the late KH. Maemun Zubair, Gus Baha, Gus Mus, and others who are clerics who have a pesantren background or who do not have pesantren but they are well-known. We see this phenomenon as part of the revival of pesantren or santri in the virtual realm. This is certainly not something sudden. The flow of information and technology media and the issue of a global village are indicative of this revival. Especially with the advent of social media web owned by Muslim militants who tend to deliver puritanical and radical teachings which increasingly have a stage in social media particularly and the internet media such as Muslimcyberarmy, eramuslim, voaislam.

Bangkitmedia.com and kyaiku.com are two news or information websites that play a role in following the dynamics of social media. They often post narratives with the nuances of kyai or clerics and pesantren. These two are substantive themes in most of the bangkitmedia.com and kyaiku.com posts.

To be clearer, the concepts, methods and approaches described in relation to virtual religious narratives by bangkitmedia.com and kyaiku.com as research objects, I discuss in the following points: a) First the narration religious digital contained in bangkitmedia.com and kyaiku.com are placed as research objects as well as autonomous subjects or centers. The digital narratives of the two webs are then positioned as ontological facts, b) Furthermore, the religious digital narratives which are considered to be 
ontological facts are understood by objectifying their structure. In this case, structural analysis occupies an important position, then c) In the next stage, understanding is broadened when the symbolization layer is represented by posting photos, profile pictures, videos and memes. It happens since the interpretation has exceeded the structure limit, d) the symbolic codes interpreted require things that are referential regarding the authorship process of the narrator/ web admin. It is related to the digital narration and the factors associated with it, e) Symbolic codes emitted by digital narratives and associated with various problems outside themselves necessitate other disciplines to complement the interpretation of digital narratives, and $f$ ) Finally, the end of the process is the discovery of meaning or message (Syahputra, 2016). From the scheme it appears that the meanings and messages in hermeneutic interpretation are in the broadest and most remote areas of the text (the virtual narrative of religion as its ontological fact), but remain within the horizon emitted by the religious virtual texts.

The admin of kyaiku.com chooses to keep his identity secret. However, I found that the anonymous admin stated blatantly that the purpose of creating the web is to benefitting virtual readers. When asked, kyaiku.com has several virtual narrative content advisors from various NU, MD and national figures. As to maintain its confidentiality, kyaiku.com also does not provide the name of anyone who is in the organizational structure of kyaiku.com, they prefer to remain anonymous in their location as well as identity while continuing to carry out their goals.

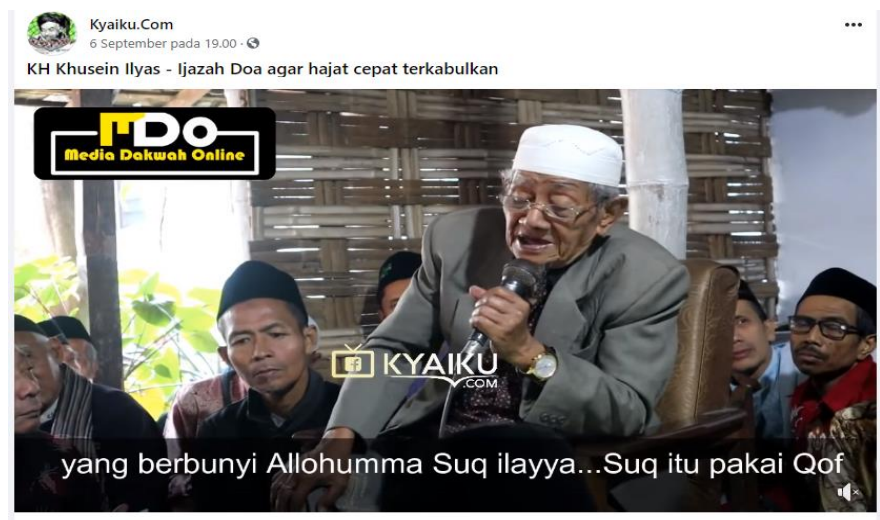

Pict 1. This is a screen shoot of a posted video by kyaiku.com. This post shows a particular a Muslim traditional cleric/kyai named Khusein Ilyas teaches their students across generations on special supplications to meet our worldly needs given by God. 


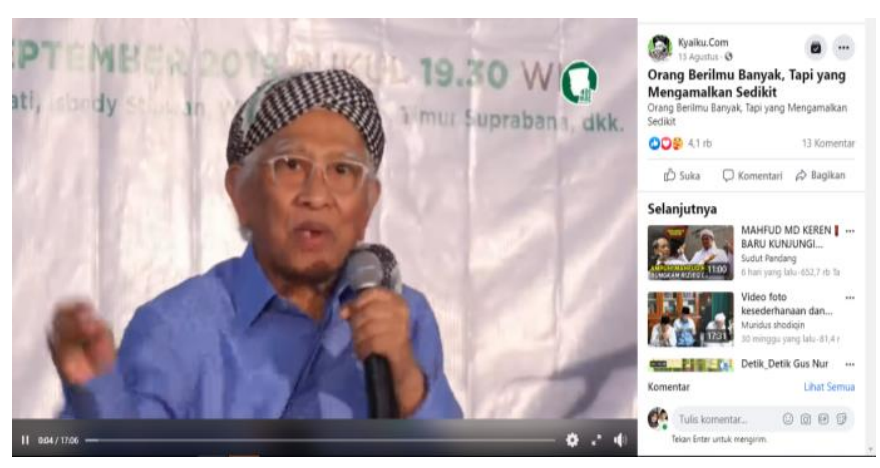

Pict 2. Another posted video by kyaiku.com showing a well renowned traditional Muslim cleric/ kyai, Gus Mus lecturing on the phenomena of numerous intellectuals while only few of them practicing righteous deeds

Bangkitmedia.com is a website that presents news themes about Islam. Features presented are 1.) News, 2.) Koran, 3.) Sermon, 4.) Education, 5.) Opinion, 6.) Culture, 7.) Maslahah Family and 8.) Figure. Unlike kyaiku.com, this website clearly writes its operational central location on Jl. MT. Haryono No. 40-42, Suryodiningratan, Mantrijeron, Yogyakarta City, and Special Region of Yogyakarta 55141. Besides that, this website also displays the editorial board in a structured manner and affirms its affiliation with NU.

In this case, Facebook and other virtual social media cannot be considered neutral in providing information and news narratives to the public. The presentation of virtual narrative production in the form of writing, pictures and videos can be seen as an exchange of meaning in a reality. It is due to that social media actually constructs such a reality, even it becomes reality itself. In the study of media studies, Fiske (1987) argues that the code is the relationship between the producer, the text and the reader and is an agent of intertextuality in which the text relates in a network of meanings that contain the cultural world that accompanies it. 


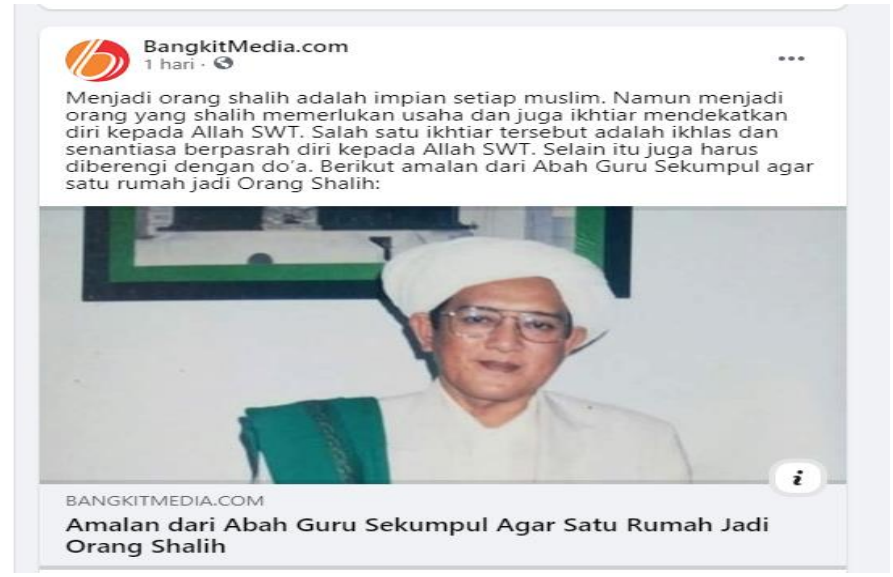

Pict 3. This is a posted photo and article by BangkitMedia.com sharing about the teaching of the late Abah Guru Sekumpul, a famous spiritual cleric in Banjarmasin Kalimantan, on the practices and efforts that can lead someone to be pious and religiously righteous.

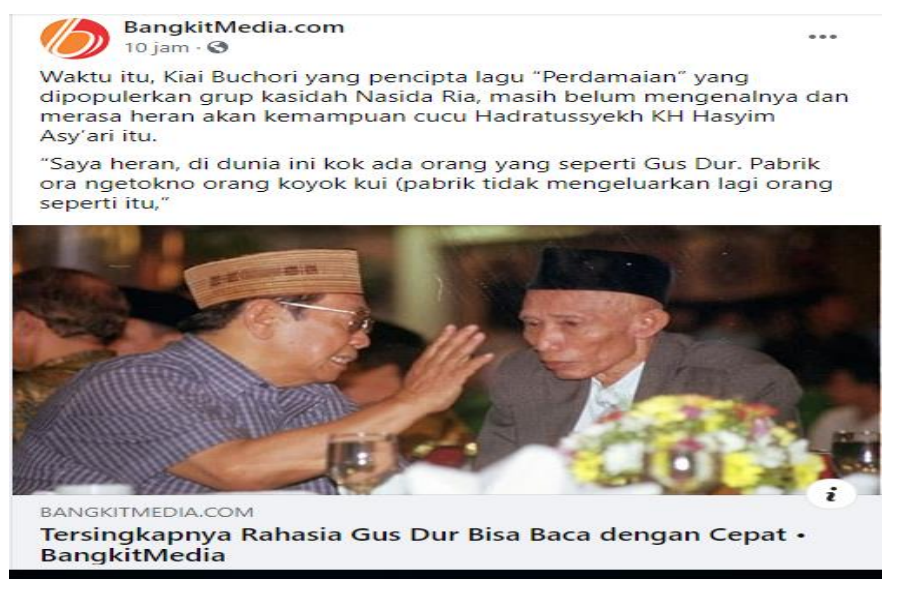

Pict 4. Another posted photo and story by BangkitMedia.com presenting two great outstanding national clerics or kyai; 1.) KH. Abdurrahman Wahid or Gus Dur, who was also the 4 Indonesian President 2.) KH. Sahal Mahfudh the former Syuriah chairman of PBNU. The story in the article tells about the secret of Gus Dur in reading fast, as the outstanding cleric, is revealed.

Based on some pictures, we could grasp that the virtual religious narratives built by the content creators of BangkitMedia.com and Kyaiku.com depend tightly on portraying authoritative Muslim traditional clerics or kyai in the content creators' point of views. By posting teachings, stories, article, and videos of the kyai, they try to convey message on how to live as Muslims keeping and enlivening traditions of the righteous ancestors with which they remain faithful while practicing so. Furthermore, it implies a counter- 
narrative of those radical Muslim groups who denies such traditions. The radical Muslim, otherwise, will claim that such things are heresies and judge the doers as heretic, misled, and even infidels.

To further analyze this issue and to answer why the webs like bangkitmedia.com and kyaiku.com go virtually public, it should be understood that the strength of the internet positioning everyone equally in providing and accessing information raises risks that cannot be fully systemically anticipated, except by so-called common sense. According to Eickelman \& Anderson (1999), the internet creates new public spaces for Muslims across groups and geographies. In Indonesia, compared to large Islamic community organizations such as Nahdlatul Ulama and Muhammadiyah, radical Islamic groups are more aggressive, quick and agile in using the internet. Interestingly, most radical sites not only provide content about jihad propaganda, but also other popular rubrics such as issues about Muslim women, teenagers, frequently asked questions of fiqh, and so on. Since the content creators are aware that not all netizens intend to access radical sites. Through such a pattern, netizens are led to visit radical sites and then eventually they roll to other writing titles that contain a paradigm of religious radicalism.

Some radical Islamic sites are always relatively higher than moderate Islamic sites like NU Online. In terms of numbers, Islamic sites that contain teachings of peace are also far less than Islamic sites that are indicated to contain radical teachings. BNPT said there are 9000 radical sites. This does not yet count Facebook, Twitter and video accounts on YouTube that propagate radical teachings. It means that if posts containing radical messages on face book, twitter and YouTube are counted, there must be more than that.

The admins/ creators of bangkitmedia.com and kyaiku.com are mindful of the aforementioned discourses since the nature of the internet as a medium of superhighway cannot really be censored. Every internet censorship effort will only further incite similar new content. For a long time, we have learned from the past that in Indonesia that pornographic content cannot be stopped, likewise with radical content. The admins fully consider that there should be strategies that can reduce the impact of radical content beyond censorship by civil society. In this case both admins do care and are attentive to two points as follow: 
First, social media work(s) should be opposed to the same work(s). Actually, that is what radical groups do, they oppose mainstream information by providing information. Now, the admins of bangkitmedia.com and kyaiku.com must fight back by flooding friendly Islamic information that is no less militant. Not a few friendly Islamic sites have sprung up to balance information. But, not all of them have the militancy to continue producing brand-new writing. As a result, these webs are seriously carried out by them as an agenda of online mainstreaming friendly Islamic information.

Second, the information must be channeled through social media to approach netizens. It is why the roles of bangkitmedia.com and kyaiku.com in posting religious wisdom from moderate Muslim figures are significant so that it will not only be read by netizens but also be reposted or re-shared. The netizens can confirm the understanding of religion to some prominent religious leaders/figures. There are a number of accounts usually flooded with questions such as@ngajigusbaha, @gusmus@nadirsyahhosen and many other young ustadzs from pesantren who began to come up with the media. In terms of twitter, netizens know, due to word character limitations in it, not all questions can be answered completely. For that reason, some of these tweets are religiously tweet lectures to respond to certain and specific problems.

Adding to that, bangkitmedia.com and kyaiku.com play roles in disseminating moderation literacy in the virtual media. The moderation literacy in social media is strongly related to the right attitude in positioning the use of social media as a social phenomenon that brings various consequences to life, such as economic, social, political, and also religious attitudes to lead to mediation between technology and audiences to practice technology appropriately and based on morality. Also, this literacy is related to the attitude of someone who can choose, determine, use, access, manage and evaluate a content or information to be able to draw the right conclusions quickly and intelligently, so that the use of social media is very precise and not wrong (Kosasih, 2019). Thus, the moderation of literacy in social media also invites users to the need for intelligence in addressing several things that occur, so it does not cause adverse effects on everyday life. There must also be a balance (balancing) that is applied by social media users in addressing something, not to be biased towards one party. 
However, what happens in social media must be dealt with in a moderate or balanced manner. As exemplified by the two websites by narrating virtual piety and Muslim traditionalism mainstreaming of kyai, Islamic preaching wisely by inviting people to do well is needed to put the brakes on or limit all negative attitudes that will pollute the sacred mission of Islam, including wisely in using various ideal means to spread Islamic preaching. Therefore, Islamic preachers must be able to use various modern means of communication that emerge in recent times to convey the essence of Islamic preaching massively and perfectly. Social media users must be very wise and prudent in receiving diverse news because it is true that of course, not all information is good and suitable for public consumption. There is some information that they (unscrupulous) spread only to mislead and trick the public. Concrete examples above, that radicalism uses the internet through social media in carrying out its actions, namely by giving bad doctrine to the wider community. Social media users must be careful and truly aware of what is happening at social media and must have a moderate attitude in receiving various information regarding religious subjects in the era of extreme use of social media.

\section{Conclusion}

Social media is indeed a very unique media which can lead to virtual community. Accordingly, there are those who are concerned with sharing religiously virtual narratives through some religious wisdom of kyai or traditional Muslim clerics as part of media literacy. Such literacy has been promoted in this regard by bangkitmedia.com and kyaiku.com. They have formed virtual piety and traditionalism mainstreaming. These two digital activism are conducted by bangkitmedia.com and kyaiku.com for fueling the media with the spirit of religious piety in order to resist hoaxes, hate speeches, provocative memes etc. They are actually and full aware that there are other webs try continuously to infuse religiously radical thoughts through social media so that they have to think the other way around for shielding such thoughts with religiously moderate narratives in the social media 


\section{Bibliography}

Bungin, B. (2009). Sosiologi Komunikasi: Teori, Paradigma, dan Diskursus Teknologi Komunikasi di Masyarakat. https://doi.org/10.1186/1758-5996-1-20

Capurro, R. (2010). Digital Hermeneutics: An Outline. AI \& Society, 25(1), 35-42.

Gunawan, F. (2012). Cyberspace dan Bahasa Alay. Kandai: Jurnal Bahasa Dan Sastra, 8(2), 137-147.

Haryatmoko. (2002). Hermeneutika Paul Ricoeur: Transparansi sebagai Proses". Basis, (5), 29.

Hoover, S. M. (Ed.). (1997). Rethinking Media, Religion and Culture. London: Sage Publication.

Horton, J. (2008). Will Social Media" Become an Oxymoron?

Informatika, K. K. (2019). No Title.

Jacobs, S. (2007). Virtually Sacred: The Performance of Asynchronous Cyber-Rituals in Online Spaces. Journal of Computer-Mediated Communication, 12(3), 1103-1121.

Kalamas, M., Mitchell, T., \& Lester, D. (2009). Modeling Social Media Use: Bridging the Communication Gap in Higher Education. Journal of Advertising Education, 13(1), 44-57. https://doi.org/10.1177/109804820901300108

Kosasih, E. (2019). Social Media Literacy on Socializing Religous Moderate Action. Jurnal Bimas Islam, 12(1), 263-296.

Lestari, A. S. \& S. R. H. (2018). Penggunaan Dan Pemaanfaatan Cyberspace Dalam Gerakan Pemikiran Hizbut Tahrir. Al Izzah: Jurnal Hasil-Hasil Penelitian, 13(1), 16-33.

Mayfield, A. (2008). What is Social Media? iCrossing.

Nasrullah, R. (2014). Teori dan Riset Media Siber (Cybermedia. Kencana.

Schuler, K. (2008). Making your Media Matter 2008 Rapporteur's Report. Washington, DC.

Syahputra, I. (2016). Agama Di Era Media:Kode Religius dalam Industri Televisi Indonesia. Esensia: Jurnal Ilmu-Ilmu Ushuluddin, 17(1).

Thurlow, C., Lengel, L., \& Tomic. (2004). A. Computer Mediated Communication Social Interaction And The Internet. Sage Publications.

Tomic, Alice Laura Lengel, Crispin Thurlow. (2004). Computer Mediated Communication Social Interaction and The Internet. California: Sage Publications.

Turkle, S. (2005). The Second Self: Computers and the Human Spirit. The MIT Press. 